\title{
DESKRIPSI MISKONSEPSI SISWA TENTANG KONSEP-KONSEP DALAM RANGKAIAN LISTRIK
}

\author{
Hamdani \\ Pendidikan Fisika, FKIP, Universitas Tanjungpura
}

\begin{abstract}
The aim of this research were investigated misconception about electric circuit. Diagnostic tests and Certainly of Response Index used to survey 68 students in Pontianak. That misconceptions are current have been consumed by its closed circuit components; the more battery in the circuits, the more brightness of the bulb; the more of resistance in series circuits, the more current; battery to be seen as stationary source of current; if a circuit element changed in a circuit, student analyse circuit in terms before and after current passes that place; if the number of resistance increase in a circuit, equivalent resistance also increases as independent from their connection type.
\end{abstract}

Keywords: misconception, electric circuit, CRI, diagnostic tests.

Fisika adalah ilmu yang mempelajari materi dan interaksinya. Pelajaran fisika yang termasuk dalam mata pelajaran IPA sepantasnya mendapat perhatian, karena banyak siswa yang mengalami kesulitan dalam belajar fisika. Hal ini dapat dilihat dari laporan TIMSS (Trend in International Mathematics and Science Study) tahun 2007 yang menunjukan dalam bidang IPA, Indonesia menduduki peringkat 35 dari 49 negara yang berpartisipasi (Litbangkemdiknas, 2008). Prestasi literasi IPA pada PISA (Programme for International Student Assesment) tahun 2009, Indonesia menempati urutan 60 dari 65 negara (Elianur, 2011). Rendahnya prestasi belajar ini disebabkan banyak faktor antara lain miskonsepsi yang dimiliki oleh siswa.

Miskonsepsi merupakan konsepsi seseorang yang berbeda dengan konsepsi para ahli (konsepsi ilmuwan). Konsepsi para ahli lebih modern, lebih komplek, lebih rumit, melibatkan lebih banyak hubungan antar konsep daripada konsepsi siswa. Umumnya miskonsepsi menyangkut kesalahan siswa dalam pemahaman hubungan antar konsep (Van den Berg, 1991).

Hasil penelitian menunjukkan bahwa miskonsepsi terjadi secara universal di lingkungan budaya, bahasa dan etnik manapun. Konsepsi dan miskonsepsi terbentuk karena interaksi dengan lingkungan. Miskonsepsi sulit untuk diperbaiki, seringkali sisa-sisa miskonsepsi terusmenerus mengganggu. Soal-soal sederhana dapat diselesaikan dengan baik tetapi dengan soal yang lebih komplek miskonsepsi muncul kembali. Sering pula terjadi regresi yaitu siswa yang sudah pernah mengatasi miskonsepsi, beberapa bulan kemudian terjadi kesalahan lagi (Van den Berg, 1991). 


\begin{abstract}
Setiap siswa yang datang ke kelas untuk mempelajari IPA mempunyai konsepsi awal tentang konsep-konsep yang sedang dipelajari. Konsepsi siswa merupakan hasil dari pengalamannya sehari-hari pada berbagai aspek kehidupannya, misalnya melalui pembicaraan dengan orang-orang yang ada di sekelilingnya, dan melalui media seperti surat kabar, televisi, radio dan sebagainya (Kurniawan, 2006). Siswa bukanlah suatu tabularasa atau kertas kosong yang bersih, yang dalam proses pembelajaran akan ditulisi oleh guru. Konsep awal yang mereka bawa itu mungkin sesuai dengan konsep ilmiah tetapi juga mungkin tidak sesuai dengan konsep ilmiah. Biasanya, konsep awal itu kurang lengkap atau kurang sempurna (Suparno, 2005) sehingga dapat menimbulkan miskonsepsi pada siswa.
\end{abstract}

Menurut paham konstruktivisme arti suatu keadaan tidak sesuai kenyataan itu sendiri (no inherent to the situation), tetapi manusia membangun sendiri arti (construct meaning) dari kenyataan itu. Arti yang dibangun oleh seseorang tergantung pada pengalaman dan tujuan yang bersangkutan daripada ditentukan oleh keadaan itu sendiri (van den Berg, 1991).

Dalam konstruktivisme, miskonsepsi merupakan hal yang wajar dalam proses pembentukkan pengetahuan oleh seseorang yang sedang belajar. Pengetahuan itu tidak sekali jadi, tetapi merupakan suatu proses terus-menerus yang semakin sempurna. Bahkan dalam perkembangan mengkonstruksi pengetahuan, siswa dapat bermula dari konsep yang sangat kasar dan sederhana serta tidak lengkap, dan pelan-pelan dalam proses pembelajaran menjadi semakin lengkap, tepat dan benar (Suparno, 2002). Dengan demikian miskonsepsi dapat dijadikan sebagai awal perkembangan pengetahuan yang lebih baik.Dalam teori belajar Piaget, untuk memahami konsep dengan baik diperlukan akomodasi pada saat proses disequilibrium. Jika pengalaman siswa dituntun pada proses ini, miskonsepsi yang terjadi pada siswa mungkin dapat dihindari.

Materi listrik dinamis merupakan salah satu materi dalam fisika yang termasuk wajib dipelajari siswa, karena menjadi landasan untuk mempelajari elektronika dan dekat dengan kehidupan sehari-hari. Siswa kadang sulit mempelajari listrik dinamis karena materinya cenderung abstrak dan kebanyakan guru menerapkan metode pembelajaran konvensional untuk mengajarkan listrik dinamis

Kesulitan belajar listrik dinamis ini kerap menimbulkan miskonsepsi pada siswa. Miskonsepsi siswa tentang kelistrikan yang berhasil diungkap antara lain jika ada dua resistor dirangkai seri, resistor dengan hambatan lebih besar memiliki arus yang lebih kecil (Bilal dan Erol, 2009); siswa menganggap dua baterai yang disusun seri atau paralel memiliki energi dan tegangan yang sama, selain itu siswa juga tidak mampu mengidentifikasi rangkaian tertutup (Engelhardt dan Beichner, 2004); besar arus listrik dalam rangkain seri berkurang pada setiap tahanan atau lampu (Darjito dan Van den Berg, 1991), lampu yang dirangkai paralel selalu lebih terang dibandingkan lampu dalam rangkaian 
tertutup seri (Kucukozer dan Kocakulah, 2007), kuat arus listrik yang mengalir pada lampu yang dekat kutub positif baterai lebih besar daripada kuat arus listrik yang mengalir pada lampu lainnya karena lampu yang dekat kutub positif baterai menerima energi listrik terlebih dahulu sehingga yang diterima lampu berikutnya lebih kecil (Mursalin, 2012). Hasil identifikasi McDermott dan Shaffer (1992) menunjukkan sebagian besar siswa mengalami kesulitan menggambarkan rangkaian tertutup ketika diminta mengilustrasikan bagaimana lampu dapat menyala dengan sebuah baterai dan kabel; baterai merupakan sumber arus yang konstan; kebanyakan siswa mengalami kesulitan mengidentifikasi rangkaian seri dan rangkaian paralel. Peneliti Brown \& Crowder, MacGregor, Philips, Hapkiewicz, Simane, Weiler (dalam Suparno, 2005) menemukan adanya miskonsepsi pada topickelistrikan semua jenjang pendidikan (SD, SMP, SMA, PT termasuk guru)

Menurut Suparno (2005) ada tiga langkah untuk mengatasi miskonsepsi yang dilakukan siswa, yaitu:

1. Mencari atau mengungkap miskonsepsi yang dilakukan siswa,

2. Menemukan penyebab miskonsepsi tersebut,

3. Memilih dan menerapkan perlakuan yang sesuai untuk mengatasi miskonsepsitersebut.

Mengungkap miskonsepsi yang terjadi, merupakan langkah awal yang harus dilakukan untuk mengatasi miskonsepsi, maka penelitian ini dilakukan untuk mengungkap bentukbentuk miskonsepsi siswa tentang rangkaian listrik

\section{Metode}

Metode penelitian yang digunakan adalah metode deskriptif dan bentuk penelitian yang digunakan dalam penelitian ini adalah penelitian survey. Metode deskriptif adalah prosedur pemecahan masalah yang diselidiki dengan menggambarkan keadaan subyek atau obyek penelitian berdasarkan fakta-fakta yang tampak atau apa adanya (Nawawi, 2005:63).Penelitian survey bertujuan untuk memperoleh fakta-fakta dari gejala-gejala yang ada dan mencari keterangan-keterangan secara faktual (Nazir,1988: 65).

\section{Subyek Penelitian}

Populasi dalam penelitian ini adalah seluruh siswa kelas XI IPA MAN 1 Pontianak. Pengambilan sampel dilakukan dengan teknik sampling jenuh. Sampling jenuh adalah teknik penentuan sampel bila semua anggota populasi digunakan sebagai sampel (Sugiyono, 2012). Jadi sampel dalam penelitian ini seleuruh siswa kelas XI IPA MAN 1 Pontianak yang berjumlah 68 siswa.

\section{Instrumen Penelitian}

\section{Tes diagnostik}

Tes ini bersifat tes konseptual yang dibuat dalam bentuk tes obyektif model pilihan ganda dengan tiga pilihan jawaban.Setiap soal dibuat untuk mendiagnosis pemahaman siswa terhadap konsep-konsep yang tercakup dalam materi rangkaian 1sitrik.Sebagian tes diadopsi dari tes Determining and Interpreting Resistive Electric Circuits Concepts Test (DIRECT) (Engelhardt \& Beichner, 2004) dan tes yang dikembangkan oleh Darjito dan Van 
den Berg (1991). Tes yang dibuat berjumlah 22 item soal.

\section{Certainty of Response Index}

Certainty of Response Index (CRI) digunakan untuk membedakan siswa yang mengalami miskonsepsi dan yang tidak tahu konsep (Hasan et al, 1999). CRI merupakan ukuran tingkat keyakinan atau kepastian responden dalam menjawab setiap pertanyaan (soal) yang diberikan. CRI biasanya didasarkan pada suatu skala dan diberikan bersamaan dengan setiap jawaban suatu soal. Tingkat kepastian jawaban tercermin dalam skala CRI yang diberikan, CRI yang rendah menandakan ketidakyakinan konsep pada diri responden dalam menjawab suatu pertanyaan, dalam hal ini jawaban biasanya ditentukan atas dasar tebakan semata. Sebaliknya CRI yang tinggi mencerminkan keyakinan dan kepastian konsep yang tinggi pada diri responden dalam menjawab pertanyaan, dalam hal ini unsur tebakan sangat kecil. Seorang responden mengalami miskonsepsi atau tidak tahu konsep dapat dibedakan secara sederhana dengan cara membandingkan benar tidaknya jawaban suatu soal dengan tinggi rendahnya indeks kepastian jawaban (CRI) yang diberikannya untuk soal tersebut (Tayubi, 2005).CRI biasanya didasarkan pada suatu skala, sebagai contoh, skala enam (0-5) seperti pada Tabel 1 (Hasan et al, 1999).

Tabel 1. CRI dan kriterianya

\begin{tabular}{|c|c|}
\hline CRI & Kriteria \\
\hline 0 & Totally guessed answer \\
\hline 1 & Almost a guess \\
\hline 2 & Not sure \\
\hline 3 & Sure \\
\hline 4 & Almost Certain \\
\hline 5 & Certain \\
\hline
\end{tabular}

Ada empat kemungkinan kombinasi dari jawaban (benar atau salah) dan CRI (tinggi atau rendah) untuk tiap responden secara individu.Untuk seorang responden dan untuk suatu pertanyaan yang diberikan, jawaban benar dengan CRI rendah menandakan tidak tahu konsep, dan jawaban benar dengan CRI tinggi menunjukkan penguasaan konsep yang tinggi. Jawaban salah dengan CRI rendah menandakan tidak tahu konsep, sementara jawaban salah dengan CRI tinggi menandakan terjadinya miskonsepsi.

Tabel 2. Ketentuan untuk membedakan antara tahu konsep, miskonsepsi, tidak tahu konsep untuk responden secara individu (Hasan, et al, 1999).

\begin{tabular}{|l|l|l|}
\hline \multicolumn{1}{|c|}{ Kriteria Jawaban } & \multicolumn{1}{|c|}{ CRI rendah (<2,5) } & \multicolumn{1}{c|}{ CRI tinggi (> 2,5) } \\
\hline Jawaban benar & $\begin{array}{l}\text { Jawaban benar tapi CRI } \\
\text { rendah berarti lucky } \\
\text { guess }\end{array}$ & $\begin{array}{l}\text { Jawaban benar dan CRI } \\
\text { tinggi berarti menguasai } \\
\text { konsep dengan baik (tahu } \\
\text { konsep) }\end{array}$ \\
\hline Jawaban salah & $\begin{array}{l}\text { Jawaban salah dan CRI } \\
\text { rendah berarti tidak tahu } \\
\text { konsep }\end{array}$ & $\begin{array}{l}\text { Jawaban salah tapi CRI } \\
\text { tinggi berarti terjadi } \\
\text { miskonsepsi }\end{array}$ \\
\hline
\end{tabular}




\section{Hasil dan Pembahasan}

Analisis data diawali dengan mentabulasi data hasil tes dalam bentuk matrik sehingga tampak nilai CRI untuk setiap item soal tes yang dicapai siswa.Kemudian proporsi siswa yang mengalami miskonsepsi dan rata-rata CRI setiap item tes dihitung. Persentase siswa yang termasuk kategori menguasai konsep, miskonsepsi, menebak (lucky guess) dan tidak tahu konsep dihitung dan ditetapkan.Persentase siswa dari setiap kategori disajikan dalam Gambar 1.

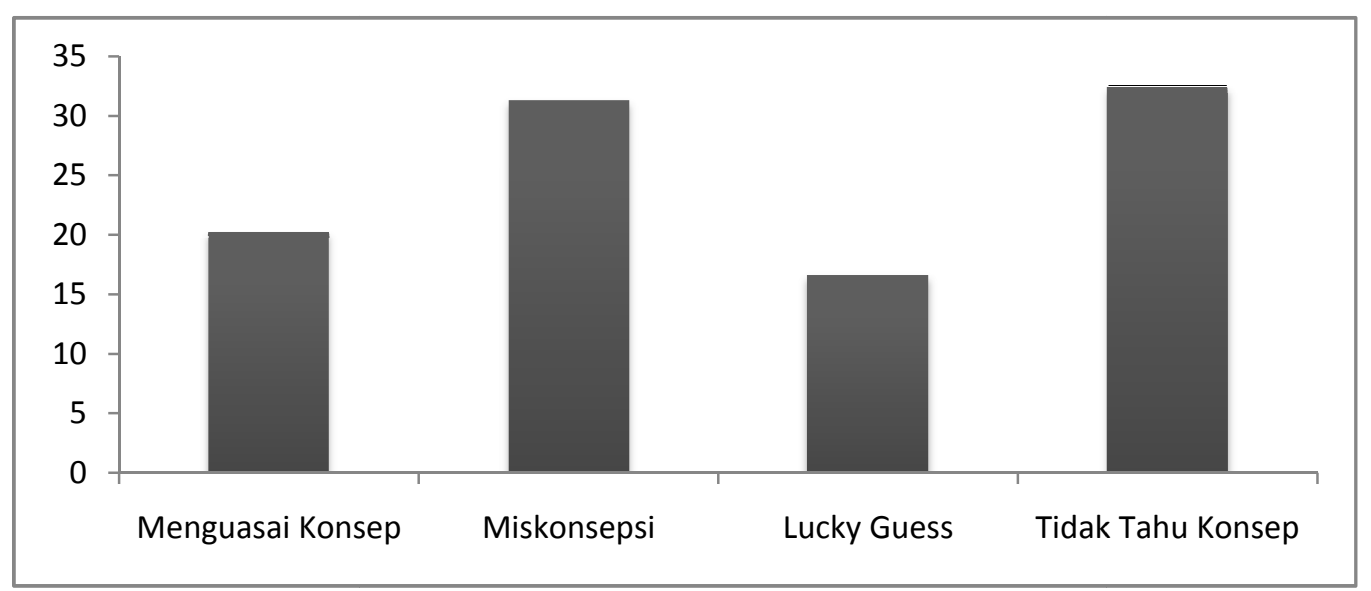

Gambar 1.Persentase distribusi kelompok siswa.

Berdasarkan Gambar 1 terlihat bahwa proporsi rata-rata siswa yang mengalami miskonsepsi dari seluruh konsep yang diteliti sebesar 31,82\% dan yang tidak tahu konsep sebesar 32,42 . Berdasarkan data tersebut sebagian besar siswa mengalami kesulitan menyelesaikan tes tentang konsep-konsep dalam rangkaian listrik.

Miskonsepsi yang dialami siswa terdapat pada semua konsep dalam rangkaian listrik yang diteliti.Berikut deskripsi bentukbentuk miskonsepsi dan besar persentase miskonsepsi yang dialami siswa.

1. Arus Listrik

Soal yang secara khusus membahas arus listrik dalam rangkaian seri ada tiga item (soal nomor 1, nomor 2 dan nomor 11).

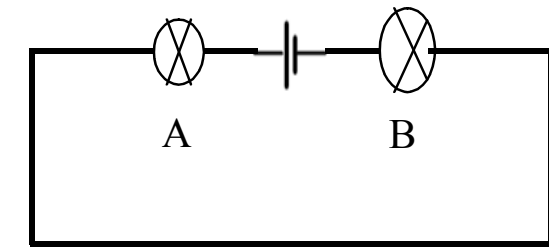

Soal nomor 1

Jika lampu identik, yang terjadi pada nyala lampu

a. Nyala lampu A lebih terangdibandingkan dengan nyala lampu B.

b. Nyala lampu B lebih terang dibandingkan dengan nyala lampu A.

c. Nyala kedua lampu sama terang.

Dari ketiga soal tersebut rata-rata $26,93 \%$ siswamengalami miskonsepsi dan 22,53\% siswa tidak tahu konsep. Pada contoh soal nomor 1, ada 10 siswa (14,7\%) beranggapan 
nyala lampu A lebih terang dibandingkan dengan nyala lampu B. Arus listrik dalam rangkaian seri berkurang pada tahanan atau lampu (consumption model). Mereka menganggap arus diserap setiap komponen rangkaian, sehingga arus yang dekat kutub posistif lebih besar dari pada arus dekat kutub negatif dari baterai (sumber daya). Hasil temuan ini didukung oleh penelitian sebelumnya yang dilakukan oleh McDermott dan Shaffer (1992), Kuckozer dan Kocakulah (2007), Darjito dan Van den Berg (1991), Duit dan Rhoneck (2000), Purba dan Depari (2008). Miskonsepsi yang lain, siswa menganggap arus mengalir dari kutub negatif ke kutub positif, arus diserap oleh komponen dalam rangkaian, sehingga arus yang dekat kutub negatif lebih besar dari arus yang dekat kutub positif.

2. Pengaruh perubahan hambatan terhadap kuat arus pada rangkaian seri

Dalam rangkaian seri, jika salah satu komponen diubah, maka seluruh rangkaian terpengaruh. Jika hambatan diubah nilainya, arus dalam rangkaian seri seluruhnya akan berubah besarnya (Darjito dan Van den Berg, 1991). Pengaruh perubahan hambatan terhadap kuat arus listrik pada rangkaian seri ditelusuri dengan 6 item soal Gambar di samping untuk soal nomor $6,12,13,14$, dan 15 .

Soal nomor 6

Jika hambatan $\mathrm{C}$ diganti dengan hambatan yang lebih besar, apa yang akan terjadi pada nyala lampu A dan $\mathrm{B}$ ?

a. Lampu A tetap sama, B meredup.

b. Lampu A meredup, B tetap sama. c. Lampu A dan B meredup.

Soal nomor 12

Jika hambatan $\mathrm{C}$ diganti dengan hambatan yang lebih besar, maka arus yang melewati lampu A akan
a. Bertambah
b. Berkurang
c. Tetap

Soal nomor 13

Jika hambatan $\mathrm{C}$ diganti dengan hambatan yang lebih besar, maka arus yang melewati lampu B akan.
a. Bertambah
b. Berkurang
c. Tetap

Soal nomor 14

Jika hambatan $\mathrm{C}$ diganti dengan hambatan yang lebih kecil, maka arus yang melewati lampu A akan.
a. Bertambah
b. Berkurang
c. Tetap

Soal nomor 15

Jika hambatan $\mathrm{C}$ diganti dengan hambatan yang lebih kecil, maka arus yang melewati lampu B akan.
a. Bertambah
b. Berkurang
c. Tetap
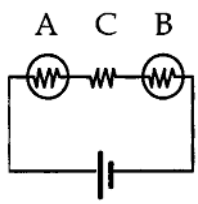

Sebaran pilihan jawaban yang keliru dengan CRI yang tinggi $(>2,5)$ disajikan dalam Tabel 3.

Pada soal no 6 ada 16 orang siswa $(23,53 \%)$ yang mengalami miskonsepsi. Miskonsepsi yang dominan, siswa menganggap lampu sebelum komponen yang diubah tetap menyala sama terang dan lampu sesudah komponen meredup (nyala lampu berubah). Pada soal nomor 12 sebagian besar siswa menganggap 
arus dalam lampu A tidak dipengaruhi oleh perubahan hambatan $\mathrm{C}$, tetapi hanya mempengaruhi arus dalam lampu B (soal nomor 13).

Tabel 3.Sebaran jumlah siswa yang miskonsepsi dan menguasai konsepuntuk konsep pengaruh hambatan terhadap arus pada rangkaian seri.

\begin{tabular}{|c|c|c|c|}
\hline No & \multicolumn{3}{|c|}{ Pilihan Jawaban } \\
\cline { 2 - 4 } Soal & A & B & C \\
\hline 6 & 10 & 6 & 19 \\
\hline 12 & 7 & 11 & 17 \\
\hline 13 & 11 & 22 & 6 \\
\hline 14 & 7 & 11 & 15 \\
\hline 15 & 17 & 15 & 6 \\
\hline
\end{tabular}

Keterangan : yang dicetak miring menandakan jumlah siswa yang menguasaikonsep.

Pola soal nomor 14 dan 15 konsisten dengan soal nomor 12 dan 13.Hal ini menunjukkan bahwa siswa beranggapan komponen yang diubah hanya mempengaruhi arus dalam komponen sesudahnya dan tidak mempengaruhi arus dalam komponen sebelumnya. Penalaran seperti ini disebut local reasoning (pengaruh perubahan rangkaian hanya lokasi saja) atau sequential reasoning (komponen yang terletak sebelum yang diubah tidak kena perubahan) (Van den Berg, 1991, Duit dan Rhoneck). Penalaran seperti ini juga ditemukan pada penelitian Darjito dan Van den Berg (1991), Duit dan Rhoneck, Purba dan Depari.

3. Pengaruh penambahan sumber tegangan pada rangkaian listrik.

Pengaruh penambahan sumber tegangan dipisahkan menjadi dua bentuk soal yaitu pengaruh penambahan sumber tegangan yang dirangkai seri (soal nomor 4) dan pengaruh penambahan sumber tegangan yang dirangkai paralel (soal nomor 20,21 dan 22).

Soal nomor 4
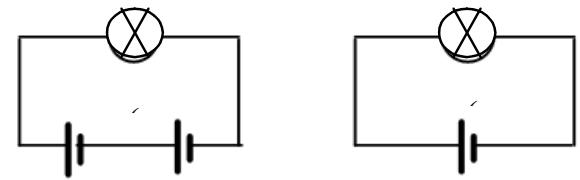

Dari gambar di atas, perbandingan nyala lampu pada rangkaian 1 dengan rangkaian 2 adalah

a. Lampu pada rangkaian 1 lebih terang.

b. Lampu pada rangkaian 2 lebih terang.

c. Keduanya sama terang.

Ada 5 orang siswa $(7,35 \%)$ yang mengalami miskonsepsi. Mereka menganggap lampu pada rangkaian 2 lebih terang karena hanya terdapat satu baterai (baterai tunggal yang dirangkai menghasilkan nyala lampu lebih terang dibandingkan dengan dua baterai yang dirangkai seri), selain itu siswa juga beranggapan baterai tunggal atau dua baterai yang dirangkai seri akan menghasilkan nyala lampu yang sama terang. Engelhardt dan Beichner (2004) juga menemukan bentuk miskonsepsi yang sama.

Gambar untuk soal nomor 21, 22 dan 23 (Asumsi baterai ideal)

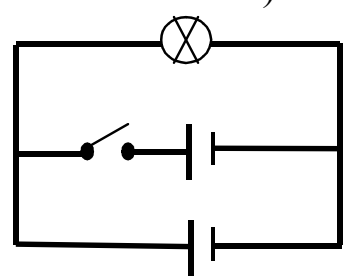

Soal nomor 21

Mula-mula saklar $\mathrm{S}$ terbuka. Jika saklar S ditutup, maka terangnya nyala lampu akan
a. Bertambah
b. Berkurang
c. Tetap

Soal nomor 22 
Jika saklar S ditutup, arus listrik yang mengalir pada lampu akan

a. Bertambah

b. Berkurang

c. Tetap

Soal nomor 23

Jika saklar S ditutup, beda potensial pada lampu akan

a. Bertambah

b. Berkurang

c. Tetap

Sebaran pilihan jawaban yang keliru dengan CRI yang tinggi $(>2,5)$ disajikan dalam Tabel 4.

Tabel 4.Sebaran jumlah siswa yang miskonsepsi dan menguasai konsep untuk konsep pengaruh sumber tegangan yang dirangkai paralel.

\begin{tabular}{|c|c|c|c|}
\hline \multirow{2}{*}{ No Soal } & \multicolumn{3}{|c|}{ Pilihan Jawaban } \\
\cline { 2 - 4 } & A & B & C \\
\hline 20 & 29 & 6 & 1 \\
\hline 21 & 22 & 9 & 3 \\
\hline 22 & 9 & 5 & 4 \\
\hline
\end{tabular}

Keterangan : yang dicetak miring menandakan jumlah siswa yang menguasai konsep.

Dari tabel 4.3 menunjukkan sebagian besar siswa yang mengalami miskonsepsi (soal nomor 21 dan nomor 22) menganggap terangnya lampu dan arus listrik akan bertambah jika sakelar dihubungkan (dua beterai dirangkai paralel). Penalaran seperti menunjukkan siswa menganggap sumber tegangan sebagai sumber arus yang tetap (Van den Berg, 1991). Pada soal nomor 22, miskonsepsi yang berhasil diungkap ada 9 siswa $(13,23 \%)$ menganggap beda potensial pada dua baterai yang dirangkai paralel lebih besar dibandingkan dengan satu baterai, dan 5 siswa $(7,35 \%)$ menganggap pada dua baterai yang dirangkai paralel lebih kecil dibandingkan dengan satu baterai.

4. Beda potensial menyebabkan arus.

Beda potensial menyebabkan arus dan tidak sebaliknya (Van den Berg, 1991). Ada 4 soal (soal nomor $16,17,18$ dan 19) yang menelusri konsep beda potensial yang menyebabkan arus.

Gambar untuk soal nomor 16,17,18 dan 19.

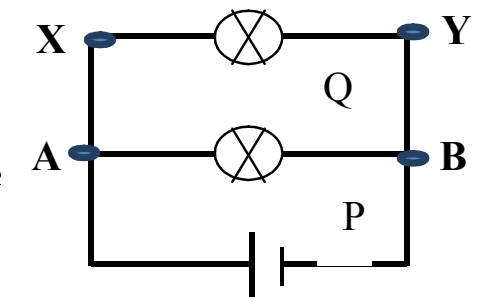

Soal nomor 16

Jika lampu P dicabut, maka yang akan terjadi adalah

a. Lampu Q akan padam.

b. Lampu Q menyala lebih terang.

c. Nyala lampu Q tidak berubah.

Soal nomor 17

Jika lampu Q dicabut, arus listrik yang mengalir pada lampu $\mathrm{P}$ akan....
a. Tetap
b. Bertambah
c. Berkurang

Soal nomor 18

Jika lampu Q dicabut, beda potensial antara titik X dan Y akan.....
a. Tetap
b. Bertambah
c. Berkurang

Soal nomor 19

Jika lampu Q dicabut, beda potensial antara titik A dan B akan....
a. Tetap
b. Bertambah
c. Berkurang

Sebaran pilihan jawaban yang keliru dengan CRI yang tinggi $(>2,5)$ disajikan dalam Tabel 5. 
Berdasarkan Tabel 5 menunjukkan siswa yang mengalami miskonsepsi (soal nomor 16 dan 17) sebagian besar menganggap terangnya lampu dan arus listrik akan bertambah jika salah satu lampu yang dirangkai paralel dilepas (dicabut). Siswa juga beranggapan beda potensial akan bertambah jika salah satu lampu dilepas (soal nomor 18 dan 19).

Tabel 5. Sebaran jumlah siswa yang miskonsepsi dan menguasai konsep untuk konsep beda potensial menyebabkan arus listrik.

\begin{tabular}{|c|c|c|c|}
\hline No & \multicolumn{3}{|c|}{ Pilihan Jawaban } \\
\cline { 2 - 4 } Soal & A & B & C \\
\hline 16 & 8 & 31 & 7 \\
\hline 17 & 12 & 24 & 6 \\
\hline 18 & 4 & 7 & 7 \\
\hline 19 & 5 & 7 & 3 \\
\hline
\end{tabular}

Keterangan : yang dicetak miring menandakan jumlah siswa yang menguasai konsep.

5. Beda potensial pada rangkaian terbuka.

Gambar soal no 8

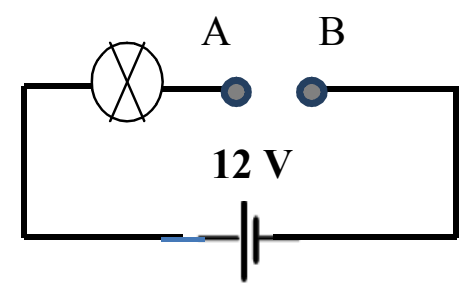

Ada 6 siswa $\quad(8,82 \%)$ yang menganggap bahwa tidak ada beda potensial antara titik $\mathrm{A}$ dan $\mathrm{B}\left(\mathrm{V}_{\mathrm{AB}}=\right.$ $0)$. Siswa menganggap pada rangkaian terbuka tidak ada beda potensial antara kutub positif dan kutub negatif baterai. Ada 7 siswa $(10,29 \%)$ yang menganggap beda potensial antara titik A dan B sebesar 6 V. Mereka menganggap beda potensial pada rangkaian terbuka sama dengan beda potensial sumber dibagi dengan jumlah titik pada rangkaian terbuka tersebut.

6. Perbandingan nyala lampu pada rangkaian seri dengan paralel

Ada 19 siswa $(27,94 \%)$ yang menganggap dua buah lampu yang dirangkai paralel akan menghasilkan nyala lampu yang lebih redup dibandingkan dengan dua buah lampu yang dirangkai seri.

7. Besar hambatan lampu pada rangkaian terbuka.

Perhatikan gambar di samping.

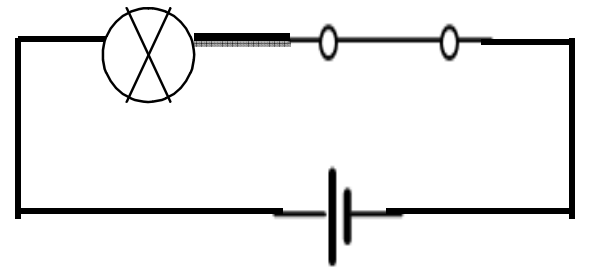

Jika saklar S dibuka, apa yang akan terjadi padahambatan lampu?

a. Hambatan lampu tetap

b. Hambatan lampu akan berkurang.

c. Hambatan lampu akan bertambah.

Ada 25 siswa $(36,76 \%)$ yang menganggap pada saat saklar S dibuka hambatan lampu akan berkurang (hambatan lampu akan berkurang pada rangkaian terbuka), dan ada 6 siswa $(8,82 \%)$ yang menganggap hambatan lampu akan bertambah pada rangkaian terbuka.

8. Arus listrik pada rangkaian campuran.

Soal nomor 10

Perhatikan gambar di bawah ini!

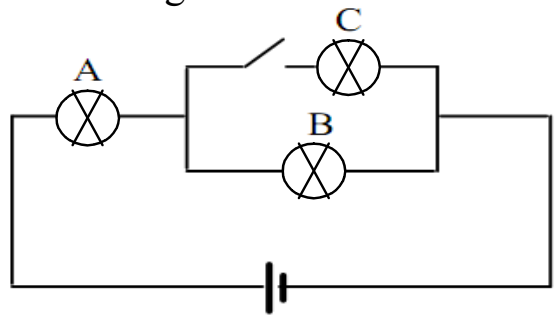


Apa yang akan terjadi pada nyala lampu A dan B jika saklar ditutup?

a. A tetap sama, B meredup.

b. A makin terang, B meredup.

c. A dan B tetap.

Ada 12 siswa (17,65\%) memilih A, ini menunjukan local reasoning juga terjadi pada soal nomor 10. Selain itu kesalahan siswa juga disebabkan karena siswa tidak mampu menentukan nilai hambatan pada rangkaian campuran. Hal ini ditunjukkan pada soal nomor 7 yang menunjukkan ada 25 siswa $(36,76 \%)$ yang kesulitan dalam menentukan hambatan pengganti pada rangkaian campuran.

\section{Simpulan dan saran}

Hasil identifikasi bentukbentuk miskonsepsi tentang konsep dalam rangkaian listrik yang berhasil diungkap antara lain Arus listrik dalam rangkaian seri berkurang pada tahanan atau lampu (consumption model), komponen yang diubah hanya mempengaruhi arus dalam komponen sesudahnya dan tidak mempengaruhi arus dalam komponen sebelumnya (local reasoning), semakin banyak hambatan dirangkai secara seri, maka arus listriknya semakin besar, baterai tunggal yang dirangkai menghasilkan nyala lampu lebih terang dibandingkan dengan dua baterai yang dirangkai seri, baterai merupakan sumber arus yang konstan, terangnya lampu dan arus listrik akan bertambah jika salah satu lampu yang dirangkai paralel dilepas (dicabut), pada rangkaian terbuka tidak ada beda potensial antara kutub positif dan kutub negatif baterai, hambatan lampu akan berkurang pada rangkaian terbuka, beda potensial akan bertambah pada rangkaian paralel jika salah satu lampu dilepas, keliru menentukan nilai hambatan pengganti dalam rangkaian campuran, nyala lampu yang dirangkai paralel lebih redup dibandingkan dengan nyala lampu yang dirangkai seri.

Miskonsepsi sulit diubah dengan pengajaran yang biasa, perlu diterapkan metode pengajaran yang meghadirkan konflik kognitif pada siswa.Beberapa metode pengajaran yang disarankan untuk mengatasi miskonsepsi antara lain learning cycle, conceptual change theory, bridging analogies, micro computerbased laboratory experiences, disequilibrium techniques, inquiry approach yang dipasangkan dengan strategi substitusi konsep, demonstrasidan diskusi, dan model pengajaran ECIRR ( Elicit-ConfrontIdentify-Resolve-Reinforce)

(Wenning, 2008), kegiatan laboratorium (McDermott dan Shaffer,1992) dan Teaching-WithAnalogy (Dilber dan Duzgun, 2008).

\section{Daftar Pustaka}

Bilal, E. dan Erol, M. (2009). "Investigating Students' Conceptions of Some Electricity Concepts".Latin American Journal of Physics Education. 3, (2), 193-201.

Dilber, R. dan Duzgun, B. (2008). "Effectiveness of Analogy on Students' Success and Elimination of Misconceptions".Latin American Journal of Physics Education. 2, (3), 174-183.

Duit, R. dan Rhoneck, C.V. (2000) Learning and Understanding 
Key Concepts of Electricity.[Online].http://www. physics.ohio-state.edu $\quad(14$ September 2012).

Engelhardt , P.V \& Beichner R.J, (2004). 'Students' understanding of direct current resistive electrical circuits".American Journal of Physics.72, (1), 98-115.

Elianur, R. (2011). Indonesia Peringkat 10 Besar Terbawah Dari 65 Negara Peserta PISA. [Online].

http://edukasi.kompasiana.com (15 mei 2012).

Van den Berg. (1991). Miskonsepsi Fisika dan Remediasi, Universitas Salatiga : Kristen Satya Wacana.

Hasan, S.D, Bagayako, D. dan Kelley, E.L. (1999). "Misconceptions and the Certainty of Response Index (CRI)."Physics Education 34, (5), 294-299.

Kucukozer.H. dan Kocakulah, S. (2007)."Secondary Scholl Students' Misconception about Simple Electric Circuits".Journal of Turkish Science Education. 1, (4), 101115.

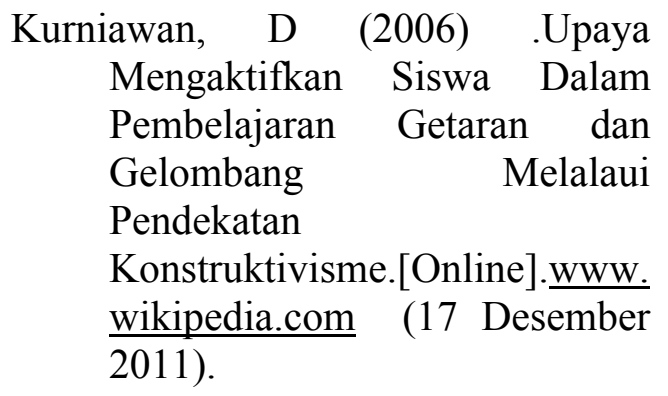

Litbangkemdiknas, (2008). TIMSS (Trends In International Mathematics and Science Study). [Online]. http://litbangkemdiknas.net/deta il.php?id=214 (15 Mei 2012).

McDermott, L.C dan Shaffer, P.S, (1992). "Research As A Guide For Curriculum Development: An Example From Introductory Electricity. Part I: Investigation of Student Understanding". American Journal of Physic. 60, (11), 994-1003

McDermott, L.C dan Shaffer, P.S, (1992). "Research As A Guide For Curriculum Development: An Example From Introductory Electricity. Part II: Design of Instructional Strategies". American Journal of Physic. 60, (11), 1003-1013.

Mursalim (2012). Model Diklat Penanggulangan Miskonsepsi Guru Fisika pada Topik Kelistrikan dan Kemagnetan melalui Simulasi Komputer. Disertasi. Tidak diterbitkan pada SPS UPI Bandung.
Nawawi.H , (2005), Metode Penelitian Bidang Sosial. Yogyakarta :Gajahmada University Press.

Nazir, Moh., 1988, Metode Penelitian, Jakarta: Ghalia Indonesia.

Purba, J.P. dan Depari, G (2008). Penelusuran Miskonsepsi Mahasiswa Tentang Konsep Dalam Rangkaian Listrik Menggunakan Certainty of 
Response Index dan Interview. [Online]http://file.upi.edu/Direk tori/FPTK/JUR. PEND. TEKN IK ELEKTRO/1947102519800

Suparno, P (2005). Miskonsepsi dan Perubahan Konsep Pendidikan Fisika.Jakarta: Grasindo.

Sugiyono (2012).Statistika Untuk Penelitian (Cetakan ke-20). Bandung: Alfabeta.

Tanel, Z. dan Erol, M. (2008). 'Students' Difficulties in Understanding the Concepts of Magnetic Field Strength, Magnetic Flux Density and Magnetization".Latin American Journal of Physics Education. 2, (3), 184-191.

Tayubi, Y.R (2005). "Identifikasi Miskonsepsi Pada KonsepKonsep Fisika Menggunakan Certainty of Response Index (CRI)". Mimbar Pendidikan. 24, (3), 4-9.
21-JANULIS P PURBA/

Makalah Seminar/miskonsepsi (Invotec).pdf (11 September 2012).

Wainwright, C.L. Toward Learning and Understanding Electricity: Chalenging Persistent Misconceptions.

[Online].http://fg.ed.pacificu.ed u/wainwright/index.html (16 September 2012).

Wenning, C.J, (2008). “Dealing More Effectively With Alternative Conceptions In Science". Journal of Physics Teacher Education Online. 5, (1), 11-19. 
